\title{
Benefit and Performance impact analysis of using hydrogen fuel cell powered e-taxi system on A320 class airliner
}

by J. A. Stockford, C. Lawson and Z. Liu

\section{ABSTRACT}

This paper presents the work carried out to evaluate the benefits and performance impacts of introducing a hydrogen fuel cell powered electric taxiing system to a conventional short-haul aircraft. Tasks carried out in this research and reported in this paper include the initial system design, hydrogen tank initial sizing, calculation of the impact on fuel burn \& emissions and the evaluation of the effects on Direct Operating Cost (DOC). The Airbus A320 has been selected as the datum aircraft for sizing the system and the benefits analysis is particularly focused on the fleet composition and financial data of a Europe based, low-cost, large-scale A320 family operator in 2016. The maximum power capacity of $400 \mathrm{~kW}$ has been sized based on the rolling friction coefficient of 0.02 . Based on the operator's 2016 financial, up to $1 \%$ fuel reduction can be achieved using the proposed system and the reduction in total maintenance cost is expected to be up to $7.3 \%$. Additionally, up to $5.97 \%$ net profit improvement is estimated in comparison with the annual after-tax profit of the datum operator in 2016.

Keywords:

Electric taxiing system; green taxiing system; hydride aircraft; powered landing gear; DOC reduction; more efficient aircraft;

\section{NOMENCLATURE}

$\begin{array}{ll}\text { ACARE } & \text { Advisory Council for Aviation Research and Innovation in Europe } \\ \text { APU } & \text { Auxiliary Power Unit } \\ \text { ASK } & \text { Available Seat Kilometres } \\ \text { ATC } & \text { Air Traffic Controller } \\ \text { LEBL } & \text { Barcelona-El Prat Airport } \\ \text { CODA } & \text { Central Office for Delay Analysis } \\ \text { DMC } & \text { Direct Maintenance Cost } \\ \text { DOC } & \text { Direct Operating Cost } \\ \text { EASA } & \text { European Aviation Safety Agency } \\ \text { ECDT } & \text { Engine Cool Down Time } \\ \text { ECS } & \text { Environmental Control System } \\ \text { EGT } & \text { Exhaust Gas Temperature } \\ \text { EGTS } & \text { Electric Green Taxiing System } \\ \text { EI } & \text { Emission Index } \\ \text { ESNZ } & \text { Åre Östersund Airport } \\ \text { ESUT } & \text { Engine Start Up Time } \\ \text { EU ETS } & \text { European Union Emission Trading System }\end{array}$




\begin{tabular}{|c|c|}
\hline FAA & Federal Aviation Administration \\
\hline FCOM & Flight Crew Operating Manual \\
\hline FF & Fuel Flow \\
\hline $\mathrm{FH}$ & Flight Hours \\
\hline FOD & Foreign Object Damage \\
\hline $\mathrm{HC}$ & Hydrocarbon \\
\hline IATA & International Air Transport Association \\
\hline ICAO & International Civil Aviation Organization \\
\hline LFBZ & Biarritz Pays Basque Airport \\
\hline LFPG & Charles De Gaulle Airport \\
\hline EGKK & London Gatwick Airport \\
\hline LLBG & Ben Gurion Airport \\
\hline LLP & Life Limited Parts \\
\hline LTO & Landing and Take-Off \\
\hline MRO & Maintenance, Repair and Overhaul \\
\hline MLW & Maximum Landing Weight \\
\hline MTBPR & Mean Time Between Parts Replacement \\
\hline MTOW & Maximum Take-off Weight \\
\hline NASA & National Aeronautics and Space Administration \\
\hline OTP & On-time Performance \\
\hline PR & Power Restoration \\
\hline $\mathrm{R}$ & Ideal Gas Constant \\
\hline SET & Single engine taxi \\
\hline SLST & Sea-level Static Thrust \\
\hline $\mathrm{T}$ & Temperature \\
\hline TET & Twin engine taxi \\
\hline TIT & Taxi-in time \\
\hline TOT & Taxi-out time \\
\hline TXI & Taxi-in \\
\hline TXO & Taxi-out \\
\hline UTS & Ultimate Tensile Stress \\
\hline V & Volume \\
\hline $\mathrm{D}_{\mathrm{o}}$ & Outside Diameter \\
\hline $\mathrm{E}_{\mathrm{APU}}$ & APU emission \\
\hline$E_{\text {dual }}$ & Dual engine emission \\
\hline $\mathrm{EI}_{\mathrm{APU}}$ & APU emission index \\
\hline $\mathrm{EI}_{\text {Eng }}$ & Engine emission index \\
\hline
\end{tabular}




$\begin{array}{ll}\mathrm{E}_{\text {single }} & \text { Single engine emission } \\ \mathrm{F}_{\mathrm{APU}} & \text { APU fuel consumption } \\ \mathrm{F}_{\text {dual }} & \text { Dual engine taxiing fuel consumption } \\ \mathrm{FF}_{\mathrm{APU}} & \text { APU fuel flow } \\ \mathrm{FF}_{\text {Eng }} & \text { Engine fuel flow } \\ \mathrm{F}_{\text {single }} & \text { Single engine taxiing fuel consumption } \\ \mathrm{n}_{\text {Eng }} & \text { Number of engines } \\ \mathrm{R}_{\text {labour }} & \text { Labour rate } \\ \mathrm{t}_{\mathrm{e}-\text { taxi }} & \text { E-taxi time } \\ \mathrm{t}_{\text {taxi }} & \text { Taxiing time } \\ \rho_{\text {jet A1 }} & \text { Density of jet fuel } \\ \mathrm{p} & \text { Pressure } \\ \mathrm{t} & \text { Wall Thickness }\end{array}$

\section{INTRODUCTION}

Modern aircraft face the challenge of reducing fuel consumption and emissions in an economically viable way. Much of the attention is focused on in-flight release of $\mathrm{CO}_{2}$. However, there is renewed importance placed on local emission of $\mathrm{CO}_{2}$ and $\mathrm{NO}_{\mathrm{x}}$ and the ACARE FlightPath 2050 Goals for emissions reduction targets aim for zero-emission taxi. An E-taxi system is based on the idea of introducing alternative power sources to achieve ground manoeuvring without the need to run the main engines. The alternative power sources can either be an external aircraft tractor or an onboard electric motor. Generally, $6 \%$ of airline total fuel budget is consumed when aircraft are operating on the ground, and an even higher proportion is consumed at congested airports [1]. Previous research findings indicate that, based on the crude oil price of US $\$ 100$ per barrel, the introduction of electric taxiing to $50 \%$ of the current narrow body airliners would contribute about $2.8 \%$ reduction in life cycle $\mathrm{CO}_{2}$ emissions per aircraft [2].

The idea of using a hydrogen fuel cell to power the electrical taxiing system is proposed. The concept intends to integrate the entire hydrogen fuel cell system (including fuel cell, hydrogen tank, controllers and waste management associations) inside a standard LD3-45W or LD3-46 air cargo container. In this way it can be located in the lower cargo hold, forming an independent power supply module which can only be activated during ground operation and is isolated during in-flight phases. With provision for electrical motors integrated on both main landing gear units, the aircraft's main engines can remain off until after taxi out and only a few minutes prior to takeoff. About 50,000 tonnes of jet fuel and associated $\mathrm{CO}_{2}$ emissions reduction per year has been initially estimated for a typical large European Low Cost Carrier. The entire project aims to study this idea in detail and attempt to assess the feasibility of applying this system on a conventional short-haul airliner. 


\section{AIRCRAFT PERFORMANCE PREDICTION METHODS}

\subsection{Taxiing Fuel Consumption and Emission}

For conventional taxiing, the taxiing phase fuel consumption and emissions for dual engine taxiing can be estimated by equation (1) and (2).

$$
\begin{gathered}
F_{\text {dual }}=t_{\text {taxi }} \times n_{\text {Eng }} \times F_{E n g} \\
E_{\text {dual }}=F_{\text {dual }} \times E_{\text {Eng }}
\end{gathered}
$$

For APU powered electric taxiing system, the only fuel consumptions during taxiing are contributed by the APU at high load condition. With the proposed fuel cell system, the APU is only required to operate at ECS mode providing cabin air-conditioning [3]. Therefore, the following equations can be applied to estimate the fuel burn and emissions based on APU operating time, fuel flow and the emission indices of the specific APU.

$$
\begin{gathered}
\mathrm{F}_{\mathrm{APU}}=\mathrm{t}_{\mathrm{e}-\text { taxi }} \times \mathrm{FF}_{\mathrm{APU}} \\
\mathrm{E}_{\mathrm{APU}}=\mathrm{F}_{\mathrm{APU}} \times \mathrm{EI}_{\mathrm{APU}}
\end{gathered}
$$

\subsection{Additional En-Route Fuel Consumption}

The application of new on-board systems creates additional fuel consumption associated with carrying the extra weight. The electric taxiing system weight varies from $136 \mathrm{~kg}$ (WheelTug) to $300 \mathrm{~kg}$ (EGTS) and this additional weight may be for compensated by less fuel carried for the taxiing phase [4] [5]. However, strict limitations for carrying taxiing fuel on e-taxiing aircraft may still be imposed by aviation authorities considering the reasons of safety [6]. According to the analysis of A320 fuel performance, the additional fuel burn for carrying every $100 \mathrm{~kg}$ of weight varies between $3 \mathrm{~kg}$ to $9 \mathrm{~kg}$ with related sector length from 1.5 hours to 3 hours [7]. Conservatively, the value of $3 \mathrm{~kg} / 100 \mathrm{~kg} / \mathrm{hr}$ has been derived and used for the estimation of additional en-route fuel consumption. For the aircraft using electric taxiing system, the amount of taxi-in fuel in each sector is no longer needed, which could partially counteract the additional en-route fuel consumption caused by extra system weight. However, this is ignored in this paper considering the safety reasons imposed by aviation authorities, which lead to a conservative fuel reduction result in the end.

\subsection{Engine Maintenance Cost}

Engine maintenance cost can be divided into three aspects which are engine performance reset cost, life-limited parts (LLP) replacement cost and foreign object damage (FOD) cost [8].

The performance reset cost is defined as the cost to restore the engine performance from deteriorating by the effect of heat, fatigue and corrosion during the routine operation in each flight cycle.

The components that are required to be replaced after a certain number of flight cycles is known as LLP which contributes about $20 \%-30 \%$ of total engine maintenance cost [9]. 
Finally, engine FOD cost covers the maintenance cost related to the damage from the foreign object. The main engines are not the only components threaten by FOD. Same damage also increases the maintenance cost of tyre and airframe. The introducing of electric taxiing system can significantly reduce the ground phase FOD cost.

\section{DATUM CLIENT BUSINESS ANALYSIS}

To quantify the performance impact brought by the e-taxi system, a Europe based, low-cost, large scale A320 family operator has been selected as the datum client and this section presents the business performance of this company in 2016 which is used in the further cost and benefit analysis in section 6 .

\subsection{Taxi-in \& Taxi-out Time Analysis}

This section covers the analysed TIT \& TOT data for the datum operator's destination airports based on the original worldwide airports taxiing time data published by CODA [10]. Table 1 presents the analysed taxiing time for datum operator's 129 destination airports in Europe.

Table 1 Summarised 2015 Taxiing Time of Datum Operator's Destinations

\begin{tabular}{lcccc} 
& \multicolumn{2}{c}{ Taxi-in Time } & \multicolumn{2}{c}{ Taxi-out Time } \\
& Time (mins) & Airport code & Time (mins) & Airport code \\
Average & 4.9 & N/A & 10.4 & N/A \\
Maximum & 9.6 & LFPG & 18.5 & LLBG \\
Minimum & 2.7 & LFBZ & 6.0 & ESNZ
\end{tabular}

The average total taxiing time for the datum operator is 15.3 minutes. To target the best hydrogen storage efficiency in a spherical tank carried in Section 4.4, 8 minutes for taxi-in and 13 minutes for taxi-out in each flight are set as the system designed maximum operating time which covers $96.9 \%$ and $88.4 \%$ of all destination airports.

The time of pushback when using EGTS is set at 1 minute which is included in the taxi-out time [1]. An additional 3 minutes are considered for both ECDT (engine cool down time) and ESUT (engine start up time) which conservatively meet the requirements of A320 FCOM (Flight Crew Operating Manual) [11]. The detailed taxiing time allocation result is presented in Figure 1 below.

\begin{tabular}{|c|c|c|c|c|c|c|c|}
\hline \multicolumn{8}{|c|}{ Total taxiing time: 21 mins } \\
\hline \multicolumn{3}{|c|}{ Taxi-in: 8 mins } & \multicolumn{3}{|c|}{ Taxi-out: 12 mins } & \multicolumn{2}{|c|}{ Pushback: $1 \mathrm{~min}$} \\
\hline $\begin{array}{c}\text { ECDT } \\
3 \text { mins }\end{array}$ & $\begin{array}{l}\text { Steady } \\
\text { state } \\
3.9 \text { mins }\end{array}$ & $\begin{array}{c}\text { Breakaway } \\
1.1 \text { mins }\end{array}$ & $\begin{array}{l}\text { ESUT } \\
3 \text { mins }\end{array}$ & $\begin{array}{l}\text { Steady } \\
\text { state } \\
7.9 \text { mins }\end{array}$ & $\begin{array}{c}\text { Breakaway } \\
1.1 \text { mins }\end{array}$ & $\begin{array}{l}\text { Steady } \\
\text { state } \\
0.8 \text { mins }\end{array}$ & $\begin{array}{c}\text { Breakaway } \\
0.2 \text { mins }\end{array}$ \\
\hline
\end{tabular}

Figure 1 Taxiing Time Allocation

Refer to the average 15.3 minutes taxiing time, by subtracting ECDT ( 3 mins) and ESUT ( 3 mins), the average electric taxiing time can be calculated as 9.3 minutes which is used as input in the benefit calculations. 


\subsection{Fleet scale in 2016}

As of 09/01/2017, the datum operator had 235 aircraft in operation including 133 A319s (equipped with CFM56-5B5/3 engines) and 102 A320s (equipped with CFM56-5B4-3 engines) [12]. Together with three different cabin configurations, the entire fleet offers 39,174 available seats. Between 2016 and 2021, this operator intends to update their fleet from a majority of A319s (156 economy class seats) to a fleet that includes over $70 \%$ of A320s (186 economy class seats) [13]. Therefore, the $\mathrm{A} 320$ is selected as the datum aircraft in this project considering the fleet composition and to ensure that the system has the capability to power the largest aircraft for the selected operator.

\subsection{Aircraft Utilisation Analysis and Flight Assignment}

$$
\text { Fleet utilisation }_{\text {Jan }}=\frac{\text { Number of flight }_{\text {Jan }}}{\text { Number of days }_{\text {Jan }} \times \text { Number of aircraft }_{\text {Jan }}}
$$

Referring to equation (5), the fleet utilisation can be calculated based on the number of flights (excluding cancelled flights), the total number of aircraft and the number of days in each month. Therefore, with 490,754 valid flights in 2016, each aircraft in the datum operator's fleet flies at least 5.91 sectors every day on average [14].. However, in the actual operation, it is unlikely to have all aircraft in service constantly. Therefore, the actual aircraft utilisation would be higher than 5.91 flights/day/aircraft which would potentially increase the system benefit so that, conservatively, the aircraft utilisation of 6 flights/day/aircraft is applied in the further analysis in this project.

\subsection{Average Sector Length}

The average sector length of datum operator in 2016 is $1,098 \mathrm{~km}$, which is approximately equivalent to the distance from London Gatwick to Barcelona [15]. According to the recorded data of flight EZ8517 (EGKK-LEBL), the average flight time is about 1.5 hours and this has been used as the average sector length in this paper [16].

\section{SYSTEM DESIGN}

\subsection{System Power Requirement and Sizing}

As the speed is relatively low during the taxiing phase, most power is used to overcome the rolling friction which is defined as the friction force opposing the motion of a freely-rolling tyre. The rolling friction coefficient is increased due to the tyre hysteresis and increasing speed, but it is common to use a constant value in ground performance calculations [17]. A recommended tyre rolling friction coefficient between 0.008 and 0.02 is also widely used in ground performance analysis [18]. The upper value of rolling friction coefficient has been considered to provide conservative approach.

The target top speed of current available and in development electrical taxiing system varies largely from $10 \mathrm{kt}$ (WheelTug) to approximately $20 \mathrm{kt}$ (EGTS). The official recommended maximum taxiing speed for A320 family aircraft is $30 \mathrm{kt}$ in straight and $10 \mathrm{kt}$ at $90^{\circ}$ turn [19]. Therefore, the target maximum taxiing speed of this system is set at $23 \mathrm{kn}$ which is close to the current aircraft taxiing speed and same as the designed operating speed of TaxiBot [20]. According to the standard safety procedures, the maximum speed for towing aircraft at ramp 
should not exceed normal walking speed $(6 \mathrm{~km} / \mathrm{h})$ which is approximately $1.67 \mathrm{~m} / \mathrm{s}$ and this is also selected as the designed push back speed for electrical taxiing system [21]. Moreover, Airbus specifies that the aircraft is required to have the ability to accelerate to $20 \mathrm{kn}$ within 90 seconds in case of crossing an active runway, which resulted in an acceleration of about $0.18 \mathrm{~m} / \mathrm{s}^{2}$ [22].

The fully integrated Intelligent Energy $100 \mathrm{~kW}$ EC Automotive fuel cell was selected as the power source for this study, which includes fuel cell stack, fuel management, air management, water management, thermal management and control module [23]. Although the maximum efficiency of the selected fuel cell is currently about $55 \%$, the value of $60 \%$ is assumed in this paper because it is the target efficiency at the technology level in 2020 which, is estimated as the time when this system enters into service [24]. Table 2 presents the summarised results of system power requirements.

Table 2 Summarised System Initial Design Results

$\begin{array}{lc}\text { Rolling friction coefficient } & 0.02 \\ \text { Acceleration }\left(\mathrm{m} / \mathrm{s}^{2}\right) & 0.18 \\ \text { Number of fuel cells } & 4 \\ \text { Motor } & \text { GKN AF-140 } \\ \text { Number of fuel motor } & 2 \\ \text { Motor weight }(\mathrm{kg}) & 42 \\ \text { Gear ratio } & 18 \\ \text { Motor speed at } 23 \mathrm{kn}(\mathrm{rpm}) & 3,482 \\ \text { Peak output power }(\mathrm{kW}) & 400 \\ \text { Peak output torque }(\mathrm{Nm}) & 21,600 \\ \text { Continuous output torque }(\mathrm{Nm}) & 9,360\end{array}$

\subsection{Energy and Hydrogen Requirement Sizing}

\subsubsection{Hydrogen requirement}

Required electric energy $=$ required electric power $\times$ operation time

$$
\text { Required hydrogen }=\frac{\text { Required electric energy }}{\text { hydrogen calorific value } \times \text { fuel cell efficiency }}
$$

Equations (6) and (7) were used to calculate the quantity of hydrogen consumed by the system. Table 3 presents the summarised results. The breakaway hydrogen requirement for taxi-out is slightly higher than taxi-in phase because MTOM and MLW is used for taxi-out and taxi-in respectively when sizing the system.

Table 3 System Hydrogen Requirement for One Flight Cycle

$\begin{array}{lccc} & \text { Taxi-in } & \text { Taxi-out } & \text { Pushback } \\ \text { Steady state } & 427 \mathrm{~g} & 1024 \mathrm{~g} & 19 \mathrm{~g} \\ \text { Breakaway } & 114.23 & 136 \mathrm{~g} & 5 \mathrm{~g} \\ \text { Total } & & 1725 \mathrm{~g} & \end{array}$

An increased total taxiing time can be caused by airport congestion. However, due to the lack of relevant input data, the method applied in this paper only considers one breakaway action for both taxi-in and taxi-out phase which may not accurately represent the frequent stop-and-go situations in congested airports. 


\subsubsection{Oxygen and water management}

Oxygen and water management is always critical for the efficiency of hydrogen fuel cell. Since the entire system is integrated inside an LD3-45W/46 container stored in the lower deck cargo hold, the analysis of the additional effects on the aircraft's ECS due to the requirement of oxygen and production of water vapour is essential. For the sized system, the additional air flow rate is estimated at $66.1 \mathrm{~g} / \mathrm{s}$. The current ECS for A320 has a capacity of providing cabin air flow rate from a minimum of $1.2 \mathrm{~kg} / \mathrm{s}$ up to $2 \mathrm{~kg} / \mathrm{s}$ [25]. Comparing with the minimum ECS performance, the estimated additional required air flow is only about $5.5 \%$ of total cabin air supply. In addition, the fuel cell system is designed only to be active when the aircraft operating on the ground so that at this stage the lower deck is not pressurised and oxygen can be easily obtained from the ambient environment so that the impact to aircraft ECS is minimal.

The extra $15.5 \mathrm{~kg}$ of water vapour produced by fuel cell in each flight cycle can be either directly drained overboard through a drain mast (such as that used for the existing water and waste system) or condensed and stored in an onboard water tank for potential use (e.g. flushing the toilet). Comparing to the 200 I potable water tank in A320, the total additional water produced by fuel cell only contains about $7.8 \%$ of tank capacity [11].

\subsection{System Packaging}

Both spherical and cylindrical tank shapes are commonly used for the hydrogen storage. Considering the relatively small hydrogen capacity requirement for the e-taxi system, the spherical tank was finally selected as it has optimal storage efficiency due to structural advantages. The system packaging method has been checked to fit in both container types used for the A320 family and demonstrated in figure 2 with the LD3-45W container as an example. The maximum tank outside radius is limited at $469.5 \mathrm{~mm}$ with $100 \mathrm{~mm}$ clearance to each wall of the container considering the tank mounting and ventilation requirements.

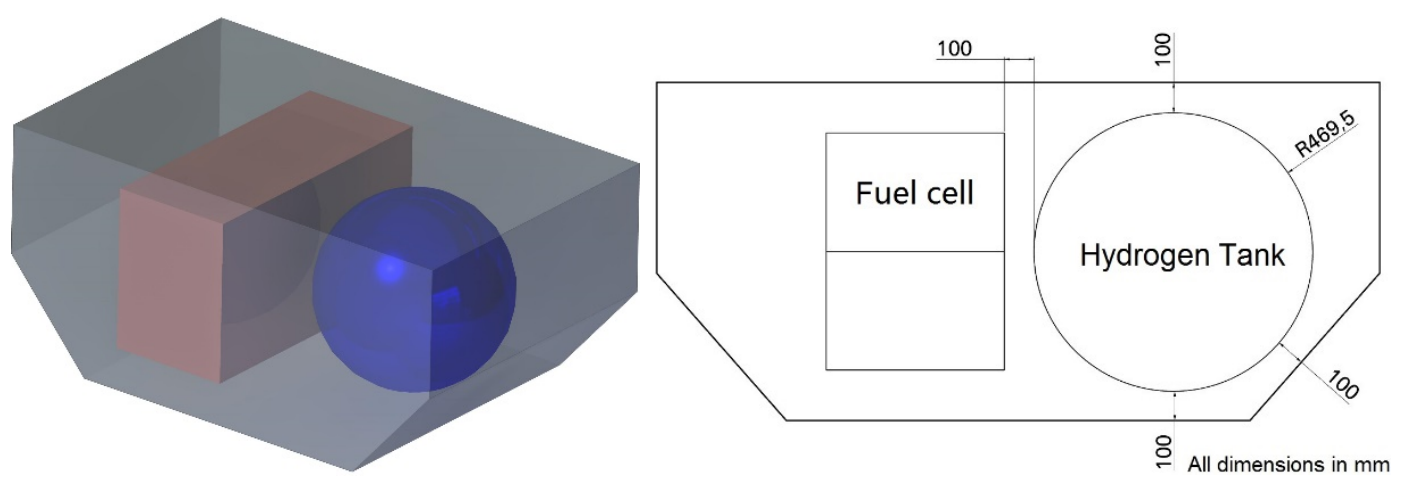

Figure 2 Packaging with Spherical Tank

\subsection{Hydrogen Tank Initial Sizing}

The ideal material for a high-pressure tank has a very high tensile strength, a low density and does not react with hydrogen or allow hydrogen to diffuse into it. High strength aluminium and stainless steel are commonly used as the materials for hydrogen tanks. As the density of steel is roughly 2.7 times that of aluminium, for the same internal pressure and outside diameter, the steel tank tends to have less wall thickness than the aluminium tank, thus providing more available inside volume. Therefore, stainless steel has been selected for the initial sizing. The tank is initially 
sized with the maximum available outside diameter and two refuelling methods have been considered.

Table 4 Spherical Tank Initial Sizing Results

\begin{tabular}{lcc}
\multicolumn{3}{c}{ Table 4 Spherical Tank Initial Sizing Results } \\
& $\begin{array}{l}\text { Refuelling every flight } \\
\text { Refuelling every day }\end{array}$ \\
Required hydrogen mass $(\mathrm{kg})$ & 1.76 & 10.56 \\
Tank mass $(\mathrm{kg})$ & 16.59 & 92.56 \\
Total mass $(\mathrm{kg})$ & 18.53 & 103.30 \\
Pressure (bar) & 62.47 & 352.53 \\
Storage efficiency $^{1}(\%)$ & 9.50 & 10.22 \\
Wall thickness $(\mathrm{mm})_{\text {Tank outside diameter }(\mathrm{mm})}^{0.76}$ & 4.30 \\
& 939 & 939
\end{tabular}

A version of the daily-fill tank using composite materials is designed in detail in [26]. This enables a mass saving of almost $10 \mathrm{~kg}$, achieving a mass of $83.21 \mathrm{~kg}$ is used for the cost and benefit analysis calculations.

\subsection{System Weight Estimation}

The weight of fuel cell system, hydrogen tank and motor can be quantified either from product specifications or detailed structural analysis. However, the weight of auxiliary parts like gearboxes, wiring and electronics cannot be accurately quantified at this stage. A rough estimation has been made by comparing to the weight of EGTS because both systems are main gear driven configurations. As the estimated system weight of EGTS is about $150 \mathrm{~kg}$ on each wheel which include one $36 \mathrm{~kg}$ motor, therefore the weight of auxiliary parts is assumed as $114 \mathrm{~kg}$ in this project [27]. Below is the weight breakdown list of two different systems with different refuelling methods.

Table 5 System Overall Weight Breakdown (excluding hydrogen)

$\begin{array}{lcc} & \text { Refuelling every flight } & \text { Refuelling every day } \\ \text { Fuel cell system }(\mathrm{kg}) & 600 & 600 \\ \text { Hydrogen fuel tank }(\mathrm{kg}) & 16.77 & 83.21 \\ \text { Motor }(\mathrm{kg}) & 84 & 84 \\ \text { Other components }(\mathrm{kg}) & 228 & 228 \\ \text { Total system }(\mathrm{kg}) & 928.77 & 995.21\end{array}$

\subsection{Alternative Method Using Lithium Batteries}

Apart from using a hydrogen fuel cell, high energy density lithium-ion batteries can also be considered as the power source for an electric taxiing system. The pack specific energy of 140 $\mathrm{Wh} / \mathrm{kg}$ and $50 \mathrm{Wh} / \mathrm{kg}$ have been proved in powering the Airbus eFan and Boeing 787 respectively [28]. The reasonable specific energy for the lithium-sulphur battery is expected to reach about $300-400 \mathrm{Wh} / \mathrm{kg}$ at the technology level of 2020 which matches the estimated service time of the electric taxiing system [28]. Therefore, relevant battery system weight at both Airbus eFan and

\footnotetext{
${ }^{1}$ The percentage of maximum stored hydrogen in comparison to the tank mass
} 
2020 technology level have been estimated for both system configurations. The weight comparison results are presented in Table 6.

\section{Table 6 System Weight Comparison between Fuel Cell and Battery Methods}

System daily required energy
Fuel cell \& hydrogen tank weight
Airbus eFan technology level

$\begin{array}{lc} & 245 \mathrm{kWh} \\ & 683 \mathrm{~kg} \\ \text { Battery pack weight } & 1750 \mathrm{~kg} \\ \text { Weight difference }^{2} & +56 \% \\ \text { Battery pack weight } & 612.5 \mathrm{~kg} \\ \text { Weight difference } & -10 \%\end{array}$

The electric taxiing system weight will be significantly increased if the fuel cell power is replaced by a lithium battery at current battery technology level. However, weight reduction can be achieved if the battery energy density of $400 \mathrm{Wh} / \mathrm{kg}$ is realised in the future. Therefore, the idea of using a battery to replace fuel cell system is still recommended in the future and relevant work can be considered as a further extension to this paper.

\section{FUEL \& EMISSION BENEFIT ANALYSIS}

\subsection{Net Fuel Reduction Analysis}

Fuel saved is generally calculated by the difference between taxiing with the main engine and with the e-taxi system in addition with extra en-route fuel burn caused by additional system weight. However, with an onboard hydrogen fuel system and daily refuelling method, the system weight gradually decreases from the first sector to the last sector of each day. This lead to the unequal additional en-route fuel consumption for each flight. In this paper, for the daily refuelling method, the additional en-route fuel burn for each single flight has been estimated and the average value has been used for the analysis of system benefit. Table 7 presents the summarised fuel reduction. For average taxiing time in 2015, comparing with twin traditional engine taxi (TET) operation, about $165.6 \mathrm{~kg}$ fuel can be saved from not operating the main engine, and about $29.7 \mathrm{~kg}$ additional fuel is burned by the APU. The additional en-route fuel consumption varies with the system overall weight and refuelling method from $34.9 \mathrm{~kg}$ to $37.4 \mathrm{~kg}$. Therefore, $101 \mathrm{~kg}$ and $98.5 \mathrm{~kg}$ fuel can be saved in each flight for daily and per-flight refuelling method respectively. However, Single engine taxi (SET) is now widely implemented in most European airport and the SET and single engine taxi without APU (SETWA) operating procedure are also included in A320 FCOM [29]. Although SET can reduce up to $40 \%$ fuel during taxiing phase comparing to TET, but the typical $30 \%$ reduction is used to calculate the fuel saved by using e-taxi system comparing with the fuel consumption with SETWA procedure. [30]. Therefore, $81 \mathrm{~kg}$ and $78.5 \mathrm{~kg}$ fuel can be saved in each flight for daily and per-flight refuelling method respectively comparing with SET.

\section{Table 7 Fuel Reduction at Each Flight}

$$
\text { Comparing to TET Comparing to SET }
$$

\footnotetext{
${ }^{2}$ In comparison with the fuel cell \& hydrogen tank weight
} 


$\begin{array}{cccc}\begin{array}{c}\text { Refuelling } \\ \text { every flight }\end{array} & \begin{array}{c}\text { Refuelling } \\ \text { every day }\end{array} & \begin{array}{c}\text { Refuelling } \\ \text { every flight }\end{array} & \begin{array}{l}\text { Refuelling } \\ \text { every day }\end{array}\end{array}$

Main engine fuel reduction $(\mathrm{kg})$

Additional APU fuel burn $(\mathrm{kg})$

Additional en-route fuel burn $(\mathrm{kg})$

Net fuel reduction $(\mathrm{kg})$
165.6

29.7
115.9

0

$\begin{array}{cccc}34.9 & 37.4 & 34.9 & 37.4 \\ 101.0 & 98.5 & 81 & 78.5\end{array}$

Combined with the number of actual flights flown by the datum operator in 2016, the estimated annual fuel reduction can be obtained. 49,566 $t$ and 48,339 $t$ annual net fuel reduction can be achieved for per-flight and daily refuelling method respectively comparing to TET operation. Similarly, 39,751 t and 38,524 $t$ annual net fuel reduction can be achieved for per-flight and daily refuelling method respectively comparing to SET operation. One of the other key factors that directly linked to net fuel reduction is the length of each mission and total time spent during the taxiing phase. Therefore, sensitivity studies have been carried to investigate the break-even boundary of fuel reduction, and are presented in Figure 3. Positive net fuel saving is more likely to be achieved on the relative short-range mission but with relative high proportion of taxiing time. This result is positive for datum operator (low-cost carrier) as their business focusing on high frequent short-range route.



Figure 3 Sensitivity Study of Taxiing Time to Net Fuel Saving (Comparing with TET)

\subsection{Hydrogen Consumption Analysis}

The annual hydrogen consumption for the datum operator in 2016 can be estimated by the required hydrogen at each flight and the total number of flights flown. This can be calculated based on the basic chemical reaction equation in addition with fuel cell efficiency. Totally 863.87 t hydrogen is estimated for the datum operator in 2016. 


\subsection{Emission Reduction Analysis}

The civil aircraft emissions near the airport are normally quantified based on ICAO engine exhaust emission databank and ICAO standard LTO cycle [31]. According to the fleet scale summarised in Section 3.2, the datum operator's A320s and A319s use different engines which have different emissions characteristics. Therefore, the lowest emission indices between these two engines are picked out and used in the calculation of emission reduction to obtain conservative results. Summarised engine emissions indices and APU emissions indices in the mode of providing ECS are presented in Table 8. The emission of $\mathrm{CO}_{2}$ is normally calculated based on the amount of fuel consumed and about 3155 grams of $\mathrm{CO}_{2}$ will be released for one kilogramme of burned modern Jet A1 fuel [32]. The reason why the $\mathrm{EI}$ of $\mathrm{CO}$ and $\mathrm{HC}$ are inversely proportional to the thrust setting is that they are the result of incomplete combustion due to the extremely low efficiency of fuel atomization and mixing in low-temperature air [33]. The emission characteristic of $\mathrm{NO}_{\mathrm{x}}, \mathrm{CO}$ and $\mathrm{HC}$ varies with different thrust settings. Engine idle thrust setting is used for taxi phase analysis and the emission index at climb out thrust setting is used in the calculation of en-route emission reduction to obtain conservative results.

\begin{tabular}{lcccc}
\multicolumn{5}{c}{ Table 8 Main Engine Emission Data [34] [32] } \\
\multicolumn{4}{c}{ Emission indices (g/kg fuel) } \\
Mode & $\mathrm{CO}_{2}$ & $\mathrm{NO}_{\mathrm{x}}$ & $\mathrm{CO}$ & $\mathrm{HC}$ \\
Take-off & 3155 & 16.42 & 0.15 & 0.02 \\
Climb out & 3155 & 14.01 & 0.16 & 0.02 \\
Approach & 3155 & 8.03 & 3.24 & 0.05 \\
Idle & 3155 & 3.81 & 32.07 & 1.92 \\
APU & 3155 & 6.85 & 5.73 & 0.43
\end{tabular}

The reduced emissions from the main engines and additional emissions from the APU and those associated with the extra weight en-route can be calculated using equation (8). Therefore, the net emission reduction can be obtained by equation (9) and the results are summarised in Table 9.

$$
\text { Emission reduction }=\text { fuel reduced } \times \text { EI }
$$

Net emission reduction

$$
\begin{aligned}
& \text { = main engine emission reduction }- \text { additional APU emission } \\
& \text { - additional en }- \text { route emission }
\end{aligned}
$$

Table 9 Average Emission Reduction in Each Flight (Refuelling each flight)

\begin{tabular}{lccccccccc} 
& \multicolumn{4}{c}{ Comparing to TET } & \multicolumn{5}{c}{ Comparing to SET } \\
& $\mathrm{CO}_{2}$ & $\mathrm{CO}$ & $\mathrm{NO}_{\mathrm{x}}$ & $\mathrm{HC}$ & $\mathrm{CO}_{2}$ & $\mathrm{CO}$ & $\mathrm{NO}_{\mathrm{x}}$ & $\mathrm{HC}$ \\
& $(\mathrm{kg})$ & $(\mathrm{g})$ & $(\mathrm{g})$ & $(\mathrm{g})$ & $(\mathrm{kg})$ & $(\mathrm{g})$ & $(\mathrm{g})$ & $(\mathrm{g})$ \\
Engine emission reduction & 522 & 5,311 & 631 & 318 & 365 & 3,717 & 441 & 222 \\
Additional APU emission & 94 & 170 & 203 & 13 & 0 & 0 & 0 & 0 \\
Additional en-route emission & 118 & 6 & 524 & 1 & 118 & 6 & 524 & 1 \\
Net emission reduction & 310 & 5,135 & -96 & 304 & 247 & 3,711 & -83 & 221 \\
Reduction rate in each LTO cycle (\%) & 24.1 & 81 & -2.13 & 58.5 & $\mathrm{~N} / \mathrm{A}$ & $\mathrm{N} / \mathrm{A}$ & $\mathrm{N} / \mathrm{A}$ & $\mathrm{N} / \mathrm{A}$
\end{tabular}

As shown in Table 9, comparing to the LTO emission data published by ICAO, the overall emission reduction is prominent especially cutting $81 \%$ of $\mathrm{CO}$ emission. However, unexpected 
increases have been found on $\mathrm{NO}_{\mathrm{x}}$ emission because the formation of $\mathrm{NO}_{\mathrm{x}}$ requires high temperature at high power setting which resulted in the en-route phase dominated emission characteristic. Therefore the $\mathrm{NO}_{\mathrm{x}}$ emission reduced during taxiing phase cannot fully counteract the penalty of the additional emission in the en-route phase.

Considering the number of flights that the datum operator flew in 2016, the estimated annual emissions reduction for the two hydrogen refuelling methods are presented in Table 10. The total annual $\mathrm{CO}$ and $\mathrm{HC}$ emissions reductions through both refuelling methods are the same, which is caused by the extremely low engine $\mathrm{CO}$ and $\mathrm{HC}$ emissions index at high power setting, so that the emission reduction is dominated by the taxiing phase when engines operate at idle setting.

Table 10 Estimated Datum Operator Annual Net Emission Reduction in 2016

$\begin{array}{lccccc} & \text { Unit } & \mathrm{CO}_{2} & \mathrm{CO} & \mathrm{NO}_{\mathrm{x}} & \mathrm{HC} \\ \begin{array}{l}\text { Refuelling every flight } \\ \text { (Comparing to TET) }\end{array} & \text { tonnes } & 156,381 & 2,520 & -30 & 149 \\ \begin{array}{l}\text { Refuelling every day } \\ \text { (Comparing to TET) }\end{array} & \text { tonnes } & 152,510 & 2,520 & -47 & 149 \\ \begin{array}{l}\text { Refuelling every flight } \\ \text { (Comparing to SET) }\end{array} & \text { tonnes } & 125,415 & 1821 & -23 & 108 \\ \begin{array}{l}\text { Refuelling every day } \\ \text { (Comparing to SET) }\end{array} & \text { tonnes } & 121,544 & 1821 & -40 & 108\end{array}$

\section{DOC BENEFIT ANALYSIS}

\subsection{Fuel Cost Reduction Analysis}

The cost of hydrogen depends on the production method, starting from $1.7 £ / \mathrm{kg}$ using biomass gasification, rising to $14.2 £ / \mathrm{kg}$ with a Photoelectrochemical method [35]. For this analysis, the current price of distributed natural gas reforming $(3.1 £ / \mathrm{kg})$ has been selected, considering about $66 \%$ of industry standard hydrogen is still produced from fossil fuel currently [36]. Therefore, the net fuel cost reduction can be calculated considering the fuel saved, fuel price hydrogen used, and hydrogen cost in equation (10). Figure 4 summarises the net annual fuel cost savings for the datum operator in 2016.

Net fuel cost reduction

$$
=\left(\text { fuel price } \times \frac{\text { net fuel reduction }}{\rho_{\text {jet } \mathrm{A} 1}}\right)-\left(\mathrm{H}_{2} \text { price } \times \mathrm{H}_{2} \text { consumption }\right)
$$




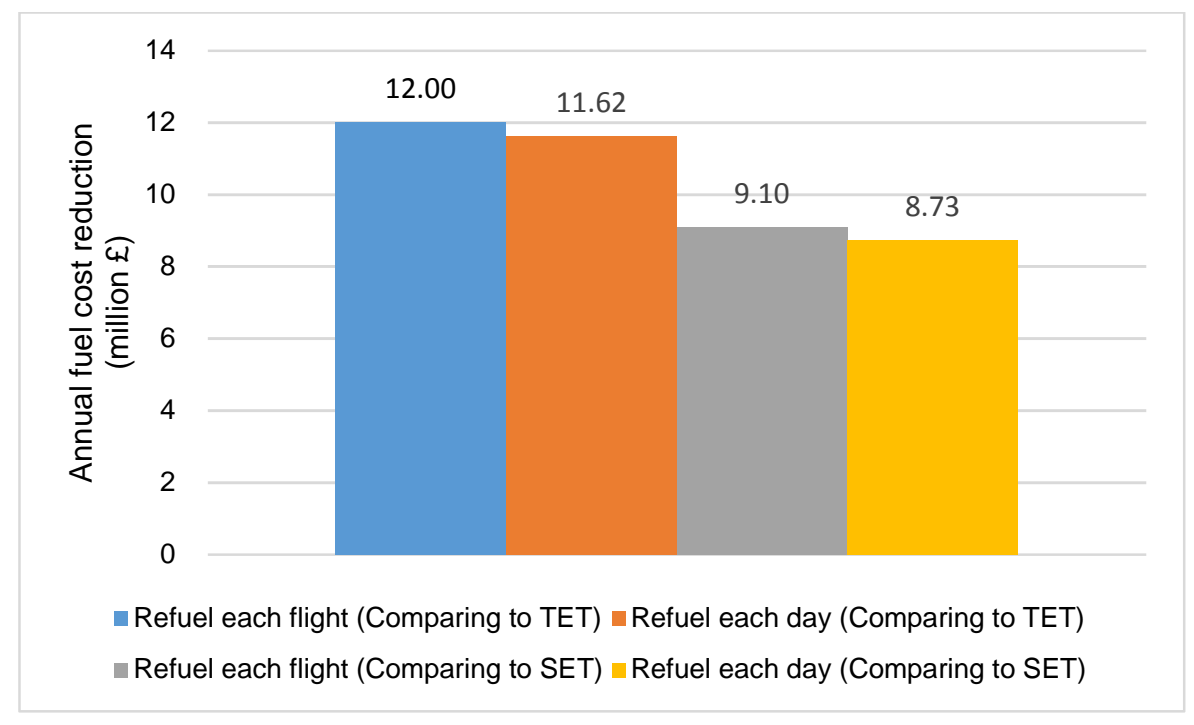

Figure 4 Estimated Net Fuel Cost Saving in 2016

Comparing with the $£ 1,114$ million annual fuel cost in 2016 of the datum operator, up to $1 \%$ of direct fuel cost reduction is estimated to be achieved by using this system. This is lower than the predicted 3\% fuel cost reduction claimed by Safran \& Honeywell [1].

\subsection{Emission Cost Reduction Analysis}

Substantial $\mathrm{CO}_{2}$ emission reduction has been proved in previous analysis. The European Union Emission Trading System (EU ETS) carbon price is determined by trading and so varies over time. In 2017 it is at a historical low (approximately $£ 3.36 / \mathrm{tCO}_{2}$ ) since the current phase of the scheme started in 2013 [37].

$$
\text { Carbon fee reduction }=\mathrm{CO}_{2} \text { reduction } \times \text { carbon price }
$$

Referring to equation (11), the reduced carbon fee has been calculated based on the ETS carbon price of $£ 3.36 / \mathrm{tCO}_{2}$ and presented in Table 11. The additional $\mathrm{CO}_{2}$ emission which could be released during the production of hydrogen is not included in this result because it is assumed to be paid from hydrogen production and included in the price of hydrogen.

Table 11 Estimated Datum Operator Annual Emission Cost Reduction in 2016

\begin{tabular}{ccccc} 
& \multicolumn{2}{c}{ Comparing to TET } & \multicolumn{2}{c}{ Comparing to SET } \\
& Refueling & Refueling & Refueling & Refueling \\
& per day & per flight & per day & per flight \\
Annual emission cost reduction & $£ 512,435$ & $£ 525,441$ & $£ 408,387$ & $£ 421,393$
\end{tabular}

\subsection{Powerplant Maintenance Cost Reduction Analysis}

\subsubsection{Main engine cost reduction}

For the flight length of 1.5 hours, engine performance reset rate of $£ 82 / \mathrm{FH}$ can be referred for CFM56-5B4 engine [8]. Therefore, following the equation (12), the estimated performance reset 
cost reduction is calculated as $\mathbf{2 5 . 4 2} \mathbf{\mathrm { E }} /$ flight. As LLPs are forced to be replaced by a certain number of flight cycles so that the reduction of engine operation time in each flight cycle will not contribute to the cost reduction of LLPs replacement. Typically, the direct FOD related engine maintenance cost is about $17 £ /$ flight and the reduced value of $10.33 \mathfrak{E} /$ flight can be obtained by using equation (13) [38].

$$
\begin{aligned}
& \text { PR cost reduction }=P R \text { rate } \times \text { electrical taxiing time } \times \mathrm{n}_{\text {eng }} \\
& \text { FOD cost reduction }=\text { FOD rate } \times \frac{\text { electrical taxiing time }}{\text { total taxiing time }}
\end{aligned}
$$

\subsubsection{Additional APU Maintenance Cost}

General maintenance cost of the APU used on the A320 is about $28 £ / A P U$ FH and the additional APU maintenance cost is estimated at about $4.34 \mathrm{E} /$ flight based on the additional APU operating time by using electric taxiing [8].

$$
\text { Additional APU cost }=\text { APU MRO rate } \times \text { electrical taxiing time }
$$

\subsubsection{Net powerplant maintenance cost reduction}

The annual MRO costs reduction for the datum operator are summarised in Table 12, based on the relevant reduction rate obtained in the preceding sections and the total number of flights in 2016.

Table 12 Summarised Datum Operator Powerplant Maintenance Cost Reduction in 2016 (Comparing to TET)

$\begin{array}{lcc} & \text { Reduced MRO cost } & \text { Reduction rate }^{3} \\ \text { Main engine cost reduction } & £ 12,474,961 & 5.3 \% \\ \text { FOD cost reduction } & £ 5,069,487 & 2.1 \% \\ \text { Additional APU cost } & £-2,129,871 & -0.9 \% \\ \text { Net cost reduction } & £ 15,414,576 & 6.5 \%\end{array}$

Table 13 Summarised Datum Operator Powerplant Maintenance Cost Reduction in 2016 (Comparing to SET)

$\begin{array}{lcc} & \text { Reduced MRO cost } & \text { Reduction rate } \\ \text { Main engine cost reduction } & £ 6,237,480 & 2.6 \% \\ \text { FOD cost reduction } & £ 2,534,743 & 1.0 \% \\ \text { Additional APU cost } & £ 0 & 0 \% \\ \text { Net cost reduction } & £ 8,772,223 & 3.7 \%\end{array}$

\subsection{Carbon Brakes Wear-Out Cost Reduction}

The high wear rate generally occurs when the brake is at relatively low temperature and the wear caused by several light brake applications is more severe than one firm brake because the wear

\footnotetext{
${ }^{3}$ Compared to the total maintenance cost of $£ 237$ million in 2016 [14].
} 
of carbon brakes is primarily dependent on the number of brake applications [39]. However, crews tend to constantly apply brakes to adjust taxiing speed because of the thrust response lag of jet engines. Therefore, the application of electrical taxiing system enables the crew to control taxiing speed more accurately, the wear-out of carbon brakes can be significantly reduced. The typical Mean Time Between Repair (MTBR) for carbon brakes is $1500-2000$ cycles and the overhaul cost of carbon brakes can be up to $£ 40,000$ [40], [41]. Generally, about $20 \%$ to $30 \%$ of a carbon brake's life is reduced through the multiple brake applications during the taxiing phase [42]. According to these data, the brake wear-out cost reduction is finally estimated at about $\mathbf{4} \mathbf{E} / \mathrm{flight}$ so that the estimated annual brakes wear-out cost reduction is $£ 1,963,015$ which is about $0.8 \%$ of the datum operator's total maintenance cost in 2016.

$$
\text { Brake cost reduction }=\frac{\text { Brake cost }}{\text { Brake life }} \times 20 \%
$$

\subsection{Gate Operation Cost Reduction}

In current gate operations, aircraft are pushed back by tractors and the process is charged typically no less than $£ 80 /$ cycle [5]. With electric taxiing system, self-pushback can be realised without the additional assistance from ground services, and the cost can be reduced substantially. However, in real operations, boarding bridge availability is sometimes limited and no pushback process is required if aircraft are parked on a remote apron. Moreover, the additional visual assistant device may be needed as the backward visibility is essential when process selfpushback. Therefore, the reduction in pushback cost can be guaranteed, but has not been quantified due to the unknown data of boarding bridge utilisation rate.

Apart from direct cost, shortened gate operation time can alternatively increase the airline profit. Simplified pushback processes directly lead to the reduced gate operating time as the crew can immediately take the action after receiving ATC clearance. Pushback time reduction of up to 2 minutes is estimated for EGTS with the eliminated tow bar connection and disconnection process [1]. Combined with the WheelTug twist operation method, total turnaround time reduction of up to 20 minutes can simply be achieved by allowing passenger boarding from both front and rear doors [5]. As aircraft can only be dispatched until the brakes are cooled below a certain specified temperature. With reduced brake application during taxiing phase, more time is gained for the brake to cool down, and so avoid the use of brake cooling fans which further improve turnaround time. The benefits explained above can be realised by using an e-taxi system. However, it is hard to quantify them in detail due to the reason of uncertainty and lack of input data at the current research stage. Some operational surveys in the future will improve the accuracy of the cost saving predictions.

\subsection{Summary of DOC Benefit}

Based on the combined effects of the above aspects, the net benefit of using a fuel cell powered electric taxiing system are summarised and presented in Table 14. Comparing with the after-tax profit of $£ 427$ million in 2016, about $5.73 \%$ net profit improvement can be achieved for the datum operator.

\begin{tabular}{lccc}
\multicolumn{4}{c}{ Table 14 Estimated Datum Operator DOC Reduction in 2016 (Comparing to TET) } \\
$\begin{array}{lccc} & \text { Total } & \text { per seat } & \text { pence per ASK } \\
\text { Net fuel saving } & £ 11,617,667 & £ 0.15 & 0.013 \\
\text { Net emission saving } & £ 525,441 & £ 0.01 & 0.001\end{array}$
\end{tabular}




$\begin{array}{llll}\text { Net maintenance saving } & £ 17,377,592 & £ 0.22 & 0.020 \\ \text { Annual DOC reduction before tax } & £ 29,520,700 & £ 0.37 & 0.034 \\ \text { Annual DOC reduction after tax } & £ 25,476,364 & £ 0.32 & 0.029 \\ \text { Improved profit after tax } & & \mathbf{5 . 9 7} \% & \end{array}$

Table 15 Estimated Datum Operator DOC Reduction in 2016 (Comparing to SET)

$\begin{array}{lccc} & \text { Total } & \text { per seat } & \text { pence per ASK } \\ \text { Net fuel saving } & £ 8,732,533 & £ 0.11 & 0.0100 \\ \text { Net emission saving } & £ 408,387 & £ 0.01 & 0.0005 \\ \text { Net maintenance saving } & £ 10,735,238 & £ 0.13 & 0.0122 \\ \text { Annual DOC reduction before tax } & £ 19,876,158 & £ 0.25 & 0.0227 \\ \text { Annual DOC reduction after tax } & £ 17,153,124 & £ 0.21 & 0.0196 \\ \text { Improved profit after tax } & & \mathbf{4 . 0 2 \%} & \end{array}$

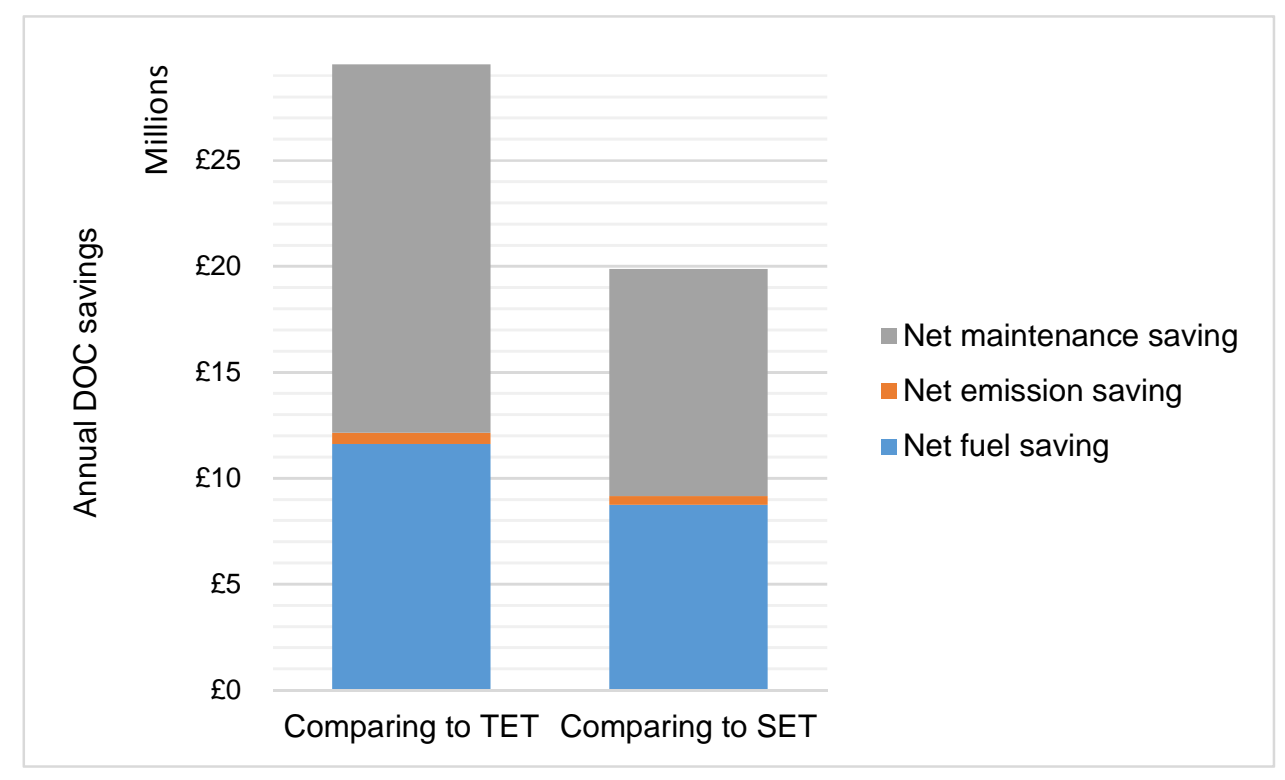

Figure 5 Annual DOC Reduction Constitution

As presented in Figure 5, the reduction contributed by fuel saving takes less than half of the total system DOC reduction. This is caused by the combination of current relatively low jet fuel price and high hydrogen production cost. A sensitivity study has been carried to investigate the potential benefit of the different combination of jet fuel and hydrogen price. As can be seen from Figure 6 , the profit improvement is more sensitive to jet fuel price than the price of hydrogen. Up to $10.5 \%$ overall profit improvement can be realised if the jet fuel price rises back to the 2012 level (about $0.55 £ / l)$.

\footnotetext{
${ }^{4}$ Overall tax rate of $13.7 \%$ [14].

${ }^{5}$ Comparing with annual after-tax profit of $£ 427$ million [14].
} 


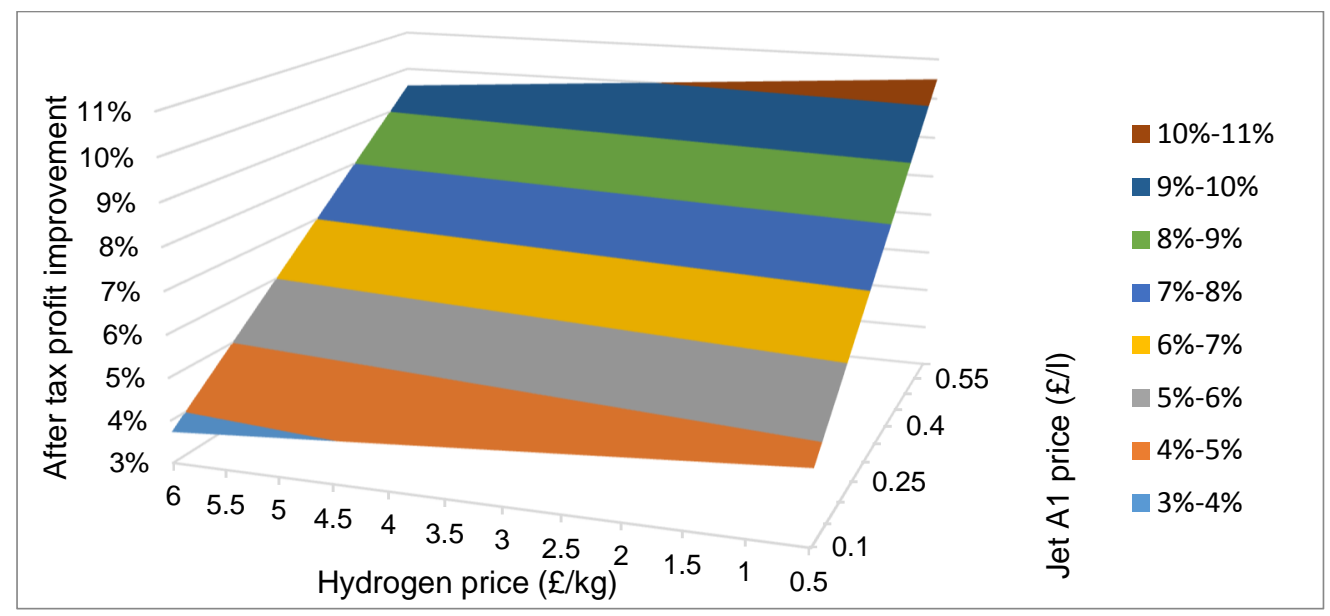

Figure 6 Sensitivity Study for the Effect of Jet Fuel and Hydrogen Price to Profit Improvement

\section{CONCLUSION}

Starting with the system initial sizing, this project focused on evaluating the performance impact of using a hydrogen fuel cell powered electric taxiing system on a midsize commercial airliner like the Airbus A320. The analysis has been applied to a typical Europe based, low-cost, larger scale A320 family operator. Using conservative estimation, a system formed of 4 fuel cells and one spherical hydrogen tank with total power output of $400 \mathrm{~kW}$ is proposed. The benefit of fuel consumption and emissions are evaluated based on the ICAO engine emission data and applied with the reduced engine operating time which is a result of using the electric taxiing system. To predict the DOC reduction and profit improvement, the evaluation process has been carried out with the conservative input parameters, such as the low taxiing fuel burn rate, high emission indices and low maintenance cost. Using the financial overview of the datum operator in 2016, up to $1 \%$ block fuel cost reduction can be achieved, and the reduction in total maintenance cost is up to $7.3 \%$. With the implementation of a hydrogen fuel cell e-taxi system, up to $5.97 \%$ net profit improvement is estimated using the annual after-tax profit of the datum operator in 2016 comparing to TET. The net profit improvement comparing to SET is about $4.02 \%$. Sensitivity studies have been carried out which indicate the potential overall profit improvement of $10.5 \%$ can be realised when the jet fuel price is at a high level as predicted for the future. Therefore, the idea of using a hydrogen fuel cell powered electric taxiing system is initially proved to have positive profit improvement for the datum operator.

This research has been based on many published operational statistics. However, cost estimations can be improved by future operational surveys focusing on the ground phases. The system design can also be refined by continuing with detailed design and integration studies. To transit from traditional taxiing to hydrogen powered e-taxiing, both airlines and airports need a transitional period to implement hydrogen storage, handling and fuelling facilities. Therefore, a hybrid system with kinetic energy recovery system and high energy-density battery may be a choice for the transitional period which using the energy recovered during landing deceleration to partially power the e-taxi system. 


\section{REFERENCES}

[1] Safran \& Honeywell, "electric green taxiing system," Safran and Honeywell, 2013.

[2] A. W. Schäfer, A. D. Evans, T. G. Reynolds and L. Dray, "Costs of mitigating CO2 emissions from passenger aircraft," Nature Climate Change, vol. 6, no. 4, pp. 412-417, 2015.

[3] Swedish FOI, "APU Emissions Database," Swedish Defense Research Agency, 2009.

[4] B. Carey, "Honeywell, Safran Demo Electric Taxiing System For Airlines," 2013. [Online]. Available: https://www.ainonline.com/aviation-news/air-transport/2013-06-18/honeywellsafran-demo-electric-taxiing-system-airlines. [Accessed 27 Feburary 2018].

[5] I. Cox, "WheelTug system, savings \& business overview," 84 2013. [Online]. Available: https://www.marketforce.eu.com/base/events/documentation/getDocument/document_id/6 32/id/19. [Accessed 27 Feburary 2018].

[6] J. Hospodka, "Cost-benefit analysis of electric taxi systems for aircraft," Journal of Air Transport Management, vol. 39, pp. 81-88, 2014.

[7] Airbus, "Getting to grips with A320 family performance retention and fuel savings," Airbus, BLAGNAC Cedex, 2008.

[8] S. Ackert, "Basics of Aircraft Maintenance Reserve Development and Management," Aircraft monitor, 2012.

[9] S. Ackert, "Engine maintenance concepts for financiers," Aircraft monitor, 2011.

[10] EUROCONTROL, "EUROCONTROL CODA," 2016. [Online]. Available: http://www.eurocontrol.int/articles/coda-publications. [Accessed 18 December 2016].

[11] EasyJet, "A319/A320 Flight Crew Operating Manual," EasyJet, 2012.

[12] Planespotters, "Easyjet Fleet Details and History," 2017. [Online]. Available: https://www.planespotters.net/airline/Easyjet. [Accessed 09 January 2017].

[13] MarketLine, “COMPANY PROFILE: easyJet plc,” MarketLine, London, 2016.

[14] OAG, "Airlines monthly OTP," OAG, 2016.

[15] EasyJet, "Results for the year ending 30 September 2016," EasyJet, Luton, 2016. 
[16] Flightradar24, "Flight history for EasyJet flight U28571," 2017. [Online]. Available: https://www.flightradar24.com/data/flights/u28571. [Accessed 11 January 2017].

[17] ESDU, "Calculation of ground performance in take-off and landing," ESDU, 1985.

[18] N. S. Currey, Aircraft landing gear design: principles and practices, 1 ed., Washington, D.C.: American Institute of Aeronautics and Astronautics, 1988.

[19] E. Parks, "Training Notes for A319/320/321," American Airlines, 2017.

[20] TaxiBot, "The world's only certified and operational Taxiing alternative," 2013. [Online]. Available: http://www.taxibot-international.com/concept. [Accessed 5 November 2017].

[21] FAA, "Towbar and Towbarless Movement of Aircraft," 27 Augest 2009. [Online]. Available: https://www.faa.gov/documentLibrary/media/Advisory_Circular/AC\%2000-65.pdf. [Accessed 29 October 2016].

[22] M. GUBISCH, "IN FOCUS: Manufacturers aim for electric taxi EIS by 2016," FlightGlobal, 21 February 2012.

[23] Intelligent Energy, "100kW EC Automotive Fuel Cell System Data sheet," Intelligent Energy Limited, Loughborough, 2015.

[24] U.S.DRIVE, "Fuel cell technical team roadmap," U.S. Department of energy, 2013.

[25] I. Martinez, "Aircraft environmental control," 1995.

[26] H. Bougad, "Feasibility study of a fuel cell powered green taxiing system on conventional A230 class airliner," Cranfield University, Bedford, 2017.

[27] E. Ganev, C. Chiang, L. Fizer and E. Johnson, "Electric Drives for Electric Green Taxiing Systems," SAE International Journal of Aerospace, vol. 9, no. 1, pp. 62-73, 2016.

[28] F. Fusalba, "Key drivers for aerospace batteries. Today and future aircrafts electrically powered," 2015.

[29] Airbus, "ICAO Seminar/Workshop," Airbus, Brasilia, 2017.

[30] E. Fleuti and S. Maraini, "Taxi-Emissions at Zurich Airport-Calculation Analysis and Opportunities," Flughafen Zürich AG, Zurich, 2017. 
[31] İ. Yılmaz, "Emissions from passenger aircrafts at Kayseri Airport, Turkey," Journal of Air Transport Management, vol. 58, pp. 176-182, 2017.

[32] ICAO, "ICAO Engine Exhaust Emissions Databank," ICAO, 2013.

[33] J. E. Penner, D. Lister, D. J. Griggs, M. McFarland and D. J. Dokken, "Aviation and the Global Atmosphere: A Special Report of IPCC Working Groups I and III," Cambridge, The Press Syndicate of The Cambridge University , 1999, p. 235.

[34] ACRP, Handbook for Evaluating Emissions and Cost of APUs and Alternative Systems, 1st ed., Washington, D.C.: National Academy of Sciences, 2012.

[35] Fuel cell technologies office, "Multi-year research, development, and demonstration plan," U.S. Department of Energy, 2012.

[36] IEA, "Hydrogen production \& distribution," IEA, 2007.

[37] P. MacDonald, "EU carbon price falls below €4," 2016. [Online]. Available: https://sandbag.org.uk/2016/09/02/eu-carbon-price-falls-below-e4-2/. [Accessed 28 December 2016].

[38] I. McCreary, "The economic cost," Insight SRI, London, 2008.

[39] G. D. Santo, "Proper operation of carbon brakes," Puerto Vallarta, 2001.

[40] J. m. SU, Z. C. XIAO, Y. Q. LIU, F. C. MENG, Z. G. PENG, L. M. GU, G. F. Li and R. P. $X I N G$, "Preparation and characterization of carbon/carbon aircraft brake materials with long service life and good frictional properties," New Carbon Materials, vol. 25, no. 5, pp. 329334, 2010.

[41] T. Kern, "Inside the American Airlines Wheel \& Brake Center," 2014. [Online]. Available: http://www.aviationpros.com/article/10361574/mro-operations-inside-the-american-airlineswheel-brake-center. [Accessed 04 January 2017].

[42] T. Allen, T. Miller and E. Preston, "Operational Advantages of Carbon Brakes," 2009. [Online].

Available: http://www.boeing.com/commercial/aeromagazine/articles/qtr_03_09/pdfs/AERO_Q309_ar ticle05.pdf. [Accessed 02 January 2017].

[43] C. Adams, "Wheel \& Brake Repair and Overhaul," Aviation maintenance, 28 June 2013. 
[44] M. Schier, F. Rinderknecht and H. Hellstern, "Electric Wheel Hub Motor for Aircraft Application," International Journal Of Renewable Energy Research, vol. 1, no. 4, pp. 298305, 2011.

[45] European Commission, "Cap on total allowances," 2013. [Online]. Available: http://ec.europa.eu/clima/policies/ets/allowances/aviation_en. [Accessed 27 December 2016].

[46] Eurocontrol, "BASE OF AIRCRAFT DATA (BADA) AIRCRAFT PERFORMANCE MODELLING REPORT," EEC Technical/Scientific, 2009. 


\section{Benefit and performance impact}

analysis of using hydrogen fuel cell

powered e-taxi system on A320 class airliner

\section{Stockford, Jack andrew}

Cambridge University Press

Stockford JA, Lawson C, Liu Z. (2019) Benefit and performance impact analysis of using hydrogen fuel cell powered e-taxi system on A320 class airliner. The Aeronautical Journal, Volume 123, Issue 1261, March 2019, pp. 378-397

https://doi.org/10.1017/aer.2018.156

Downloaded from Cranfield Library Services E-Repository 